Please do not remove this page

RMIT

UNIVERSITY

\title{
Peak electricity demand and social practice theories: Reframing the role of change agents in the energy sector
}

Strengers, Yolande

https://researchrepository.rmit.edu.au/esploro/outputs/9921858708401341/filesAndLinks?institution=61RMIT_INST\&index=null

Strengers, Y. (2012). Peak electricity demand and social practice theories: Reframing the role of change agents in the energy sector. Energy Policy, 44, 226-234. https://doi.org/10.1016/j.enpol.2012.01.046 Document Version: Accepted Manuscript

Published Version: https://doi.org/10.1016/j.enpol.2012.01.046

Repository homepage: https://researchrepository.rmit.edu.au

(C) 2012 Elsevier Ltd

Downloaded On 2023/04/26 12:33:22 +1000

Please do not remove this page 
Thank you for downloading this document from the RMIT Research Repository.

The RMIT Research Repository is an open access database showcasing the research outputs of RMIT University researchers.

RMIT Research Repository: http://researchbank.rmit.edu.au/

\section{Citation:}

Strengers, Y 2012, 'Peak electricity demand and social practice theories: Reframing the role of change agents in the energy sector', Energy Policy, vol. 44, pp. 226-234.

See this record in the RMIT Research Repository at:

https://researchbank.rmit.edu.au/view/rmit:16284

Version: Accepted Manuscript

Copyright Statement: (C) 2012 Elsevier Ltd

Link to Published Version:

http://dx.doi.org/10.1016/j.enpol.2012.01.046 


\title{
Peak electricity demand and social practice theories: reframing the role of change agents in the energy sector
}

\author{
Yolande Strengers ${ }^{\mathrm{a}}$ \\ a'Centre for Design, RMIT University, GPO Box 2476, Melbourne, VIC, 3001, \\ Australia, email: yolande.strengers@rmit.edu.au, phone: +61 399251916
}

\begin{abstract}
Demand managers currently draw on a limited range of psychology and economic theories in order to shift and shed peak electricity demand. These theories place individual consumers and their attitudes, behaviours and choices at the centre of the problem. This paper reframes the issue of peak electricity demand using theories of social practices, contending that the 'problem' is one of transforming, technologically-mediated social practices. I reflect on how this body of theory repositions and refocuses the roles and practices of professions charged with the responsibility and agency for affecting and managing energy demand. The paper outlines three areas where demand managers could refocus their attention: (i) enabling co-management relationships with consumers; (ii) working beyond their siloed roles with a broader range of human and non-human actors; and (iii) promoting new practice 'needs' and expectations. I conclude by critically reflecting on the limited agency attributed to 'change agents' such as demand managers in dominant understandings of change. Instead, I propose the need to identify and establish a new group of change agents who are actively but often unwittingly involved in reconfiguring the elements of problematic peaky practices.
\end{abstract}

Keywords: demand management, social practice theory, peak demand 
Acknowledgements: Many thanks to members of the Centre for Design’s

'Beyond Behaviour Change’ reading group

(http://www.rmit.edu.au/cfd/beyondbehaviour) for fascinating discussions on this topic and suggestions for review; in particular Dr Cecily Maller, Helaine Stanley and Professor Ralph Horne. I am also grateful for the constructive feedback on previous drafts of this paper provided by Professor Elizabeth Shove, Professor Gay Hawkins, Professor John Fien and Dr Zoe Sofoulis, as well as the insightful suggestions from two anonymous reviewers. 


\section{Introduction}

Peak electricity demand is a pressing international energy policy concern, causing widespread blackouts and increasing the cost of electricity for all consumers. In Australia alone, billions of dollars in investment are being used to upgrade electricity distribution and transmission infrastructure, and build generation plants to provide power during periods of peak demand. Despite these efforts (and in some cases because of them), there are growing concerns about the frequency of blackouts, particularly on hot summer days when residential air-conditioning demand adds disproportionately to peak loads (Wilkenfeld 2004). Consequently, a range of demand management strategies have emerged, such as time-of-use pricing and consumption feedback, to educate and incentivise consumers to shift or reduce peak demand.

The primary purpose of this conceptual paper is not to contribute towards existing debates about where demand management programs and peak electricity investment would be best targeted, but rather to reframe the issue entirely. The focus is on how the 'problem' of peak electricity demand and the demand management 'solutions' it generates emerge from a particular construction of reality that places humans and their minds at the forefront of social order. This humanist perspective continues to dominate into the $21^{\text {st }}$ century (Schatzki 2001), and is the foundation for the production of knowledge, policy and programs intended to achieve social and environmental transformation in an era of climate change and resource uncertainty (Shove 2010). In the context of peak electricity demand, this construction is most evident in policies and programs which attempt to 'shift' and 'shed' consumer demand. 
This paper departs from this dominant understanding of social order and change, instead drawing on social practice theories as 'a distinct social ontology', whereby 'the social is a field of embodied, materially interwoven practices' (Schatzki 2001: 3). Social practice theories depart from accounts that privilege social totality (social norms), institutions or systems (structure), cultural symbols and meanings (symbolism), or attitudes, behaviours and choices. They also overcome common dualisms which manifest themselves in the energy and resource sectors, such as supply and demand, consumption and production, or behaviour and technology. In this paper, I demonstrate how they can reframe the issue of peak electricity demand as one of changing and shifting technologically-mediated social practices, resulting in different foci for demand managers assigned the role of affecting change.

This is not primarily a debate or discussion about theory, but about the ways in which theory 'works on' policy and manifests itself in energy strategy. While theories can only ever be abstractions and constructions of reality, they can and do have quite profound effects on it. As Shove (2011: 264; emphasis in original) argues, the value of alternative theories of social change is to 'generate different definitions of the problem', not to provide a more 'holistic' perspective or to solve existing policy (and resource management) problems. Alternative perspectives are particularly necessary for the energy sector, where a unified body of theory, research and practice has served to construct and reinforce clear knowledge, processes and policies for the task of managing demand.

In addition to recasting the peak demand problem, this paper aims to identify what this reframing might mean for the professions charged with the responsibility and 
agency for steering demand, and how it might reorient the practice of doing and being a 'change agent' in the energy sector. Traditional change agents are most clearly exemplified in their roles as demand managers, where their primary task is to deploy a range of instruments such as pricing incentives and disincentives, educational and informational strategies (e.g. consumption feedback), and technological solutions intended to shift or shed energy demand. For the purposes of this paper I use the term 'demand manager' broadly to refer to a range of professions, such as load managers, consumer and customer relations teams, smart metering program managers, behaviour change practitioners, energy efficiency advisors, and network pricing managers. While not all of these professions might identify themselves as demand managers, they are variously involved in attempting to steer, redirect or intervene in consumer demand through a range of programs, incentives and technological intermediaries that they deliver and/or promote.

I begin by examining the self-reinforcing demand management paradigm and how it is employed to understand and frame energy problems (Section 2), before presenting social practice theories as an alternative perspective (Section 3). In Section 4 I discuss the ways in which social practice theories potentially reposition the problem of peak electricity demand and the role of demand managers, before identifying three different foci for these professions (Section 5). Section 6 attends to the different ways in which agency is assigned and agents identified between these different understandings of people and their demand, and what this means for who or what can be a considered a change agent. I argue for the establishment and identification of a new breed of change agents who are actively but often unwittingly involved in reconfiguring the elements of 
problematic 'peaky practices’. However, I warn that assigning certain professions (but not others) with the agency to affect social change may be misleading and unhelpful in achieving it.

\section{The supply-demand divide: a self-reinforcing paradigm}

In the energy sector, the dominant paradigm is one where supply is split from demand, with technological efficiency on one side and behavioural improvements on the other. Consumers are framed as rational, self-interested and autonomous agents, whereas technology is viewed as 'an impartial, instrumental tool in a "win-win” scenario that couples economic growth with environmental improvement' (Hobson 2006: 319). This divided view encourages a two-tiered approach to energy management problems that prioritise separate supply-side and demand-side solutions.

In the case of peak electricity demand, focusing on the supply-side by upgrading electricity infrastructure and generation capacity is often viewed as economically inefficient investment. In Australia, for example, this peak capacity is only required for 1-2 per cent of year (ETSA 2007) and causes widespread blackouts on hot summer days, leaving householders vulnerable to the effects of heat (Maller \& Strengers 2011; Strengers \& Maller 2011). While a range of household appliances are implicated in peaky practices, such as televisions, heaters, home computers, refrigerators, pool pumps, washing machines and dishwashers (Pears 2004), the air-conditioner has attracted particular attention as a 'culprit' appliance, primarily as a result of its rapid diffusion and increasing penetration (DEWHA 2008). Similar scenarios are playing out internationally, focusing demand managers’ 
attention on air-conditioning (and other peak) load during peak periods (Herter 2007; Strengers 2010a).

Popular demand-side solutions include variable pricing regimes, consumption feedback and 'direct load control' (the remote control of appliances with a high load during peak times). These strategies are often facilitated through government mandates for smart metering (Darby 2010). Additionally, governments, nongovernment organisations and energy utilities employ a range of behavioural strategies to curb demand, such as informative websites and books about how to save energy, and educational programs and campaigns designed to assist people in making more resource-efficient decisions and investments about their consumption.

To undertake these tasks, demand managers draw on a unified collection of human-centred psychological and economic theories, which Elizabeth Shove (2010) has termed the 'Attitudes, Behaviour, Choice' (ABC) model. While Shove originally posited and critiqued the ABC model as the foundation for strategies designed to encourage energy conservation and reduce greenhouse gas emissions, it is equally applicable to the other key objective of demand management, which is to shift demand to non-peak times of the day. When load shifting is the primary aim, the focus of the ABC model is expanded to include the transfer of demand management skills to energy consumers. Householders are expected to transform into micro resource-managers (Strengers 2011b), and are represented as 'Mini-

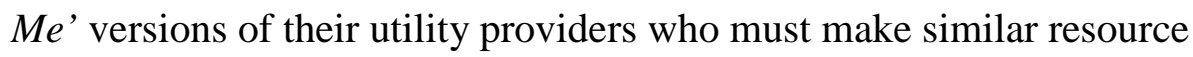
management decisions at the household level (Sofoulis 2011). The aim is to encourage consumers to make autonomous and cost-reflective decisions about the 
scheduling of their consumption (in accordance with their attitudes, behaviours and choices) through incentives and disincentives such as variable pricing tariffs. To highlight this additional emphasis of demand management, I graft a ' $\mathrm{D}$ ' for 'Demand' onto Shove's ABC model for the purposes of this paper.

This ABCD model pervades energy policy and management, and is reinforced by the plethora of consumer- and demand-oriented opportunities open to researchers, industry and community groups to respond to discussion documents and granting schemes. For example, an Australian Energy Market Commission review with the telling title 'Power of choice - giving consumers options in the way they use electricity’ (AEMC 2011), asked for responses to a series of pre-defined questions aimed at identifying consumer 'drivers', 'choices' and information needs. Here a series of epistemological and ontological assumptions about how humans understand their world, act within it, acquire new knowledge, and instigate change are adopted from the outset. The emphasis is on changing and responding to what is going on in the minds of individual consumers.

Similarly, a recent surge of international reports focused on the 'consumer domain’ (CEA 2011), ‘consumer impacts’ (NERA 2008), ‘maximizing consumer benefits’ (SGA 2011), and ‘the new energy consumer’ (Accenture 2011; Zpryme 2011), reinforce and sustain the ABCD model by focusing on the human mind and its attitudes, opinions, drivers, values and choices. My intention is not to suggest that this entire collection of theories is completely wrong or invalid, but rather to acknowledge it as such, that is, as a unified compilation of concepts that dominates and pervades energy management and policy at the exclusion of others. 
There is now a well-established critique of this dominant understanding of demand including its limitations in achieving long-lasting transformation in the ways we think about and use resources such as energy (Guy \& Shove 2000; Kempton \& Montgomery 1982; Lutzenhiser 1993; Shove 2003; Southerton et al. 2004; Wilhite et al. 2000; Wilk \& Wilhite 1985). Common critiques (and alternative framings) highlight the limited ability and willingness of consumers to make autonomous and rational decisions (Southerton et al. 2004), and the role that technologies and infrastructures play in mediating and co-shaping demand (Van Vliet et al. 2005).

One pervasive and problematic assumption underpinning the ABCD model is that demand managers must preserve, maintain and in some cases enhance existing lifestyles in accordance with individuals' attitudes, choices and values. In current energy policy and management, the emphasis is on reducing or shifting demand, 'without affecting the service provided', (NERA 2008: 17), and 'in a way that avoids significant impacts on comfort and lifestyle' (Reidy 2006: 4). The discourse is one where demand is shifted or shaved, while the services it provides are maintained and sometimes enhanced. What is lacking is an understanding that practices, and the demand they create or require, are constantly changing, often in unpredictable and unexpected ways (Shove 2003).

The idea of upholding existing ways of life is quite strange when we consider the scale and rate at which everyday practices are currently and constantly changing. For example, histories of domestic technologies (Schwartz Cowan 1989) and comfort (Cooper 1998) mark dramatic changes in what we consider to be normal cleaning, heating and cooling practices. In Australia, air-conditioning penetration 
has almost doubled in the last ten years to about 65 per cent, marking a dramatic change in how Australians keep cool in their homes (DEWHA 2008). Similarly, there have been rapid changes in home computing and entertainment practices, resulting in an increase in appliances and gadgets such as laptops, smart phones, game consoles and home theatres (Harrington et al. 2006), The ABCD model masks the complexity of these changing socio-technical configurations of ‘normality’ across different timeframes, places and cultures (Shove 2003). However, while there is now clear recognition that alternative paradigms and ways of understanding change are required, little attention has been paid to what this might mean for demand managers and the problem of peak electricity demand.

\section{A social practice perspective}

There is no unifying agreement or definition of social practice theories, yet the list of issues to which theorists are now contributing is rich and diverse (Schatzki 2001). This paper refers to these theories interchangeably as 'practice theory' 'social practice theory’ and a 'social practice perspective'. In this paper, I am interested in the 'organization, reproduction, and transformation of social life' (Schatzki 2001: 1), or the ways in which social practice theory constructs a distinctive social ontology, which differs markedly from that of the ABCD model. Table 1 helps to situate and clarify some of the distinctions between social practice and ABCD theories. It begins by highlighting a simple yet significant premise: that the world is constructed and ordered by social practices, rather than individuals and their attitudes, behaviours or choices. In this sense, practice theory: 
expresses itself decisively in a rejection of the modern conviction that mind is the central phenomenon in human life: the source of meaning, the receptacle of knowledge or truth, the wellspring of activity, and the co- or sole constitutor of reality. ... Practices, in sum, displace mind as the central phenomenon in human life (Schatzki 2001: 11)

This does not mean that individuals become redundant or unnecessary, but rather that 'practices are the source and carrier of meaning, language, and normativity' (Schatzki 2001: 12), or as Reckwitz (2002b: 254) argues: 'wants and emotions ... do not belong to individuals but —in the form of knowledge — to practices' (see Table 1). In this sense, beliefs, attitudes and values_-the common building blocks of the ABCD model—can be thought of as arising from (and being cultivated within) practices rather than people. Individuals take on a very specific role in social practice theories as 'carriers' or 'performers', who are both 'captured' by practices and simultaneously constitute them through their reproduction of them (Shove \& Pantzar 2007: 156). 
Table 1: Contrasting assumptions from $A B C D$ and social practice theories

\begin{tabular}{|c|c|}
\hline ABCD theories & Social practice theory \\
\hline The world is populated by people & The world is populated by practices \\
\hline $\begin{array}{l}\text { People and their barriers, drivers, } \\
\text { attitudes, values, opinions, choices } \\
\text { and/or norms are the central unit of } \\
\text { analysis and change }\end{array}$ & $\begin{array}{l}\text { Practices (and their elements) are the } \\
\text { central unit of analysis and change }\end{array}$ \\
\hline $\begin{array}{l}\text { Emphasis on changing people and } \\
\text { their consumption/ demand }\end{array}$ & $\begin{array}{l}\text { Emphasis on the changing elements of } \\
\text { practices }\end{array}$ \\
\hline $\begin{array}{l}\text { Technology, supply systems and } \\
\text { people are separate from each other }\end{array}$ & $\begin{array}{l}\text { Technologies and supply systems are } \\
\text { elements of practices }\end{array}$ \\
\hline People have agency & $\begin{array}{l}\text { Practices, people and things have } \\
\text { agency }\end{array}$ \\
\hline $\begin{array}{l}\text { People change through targeted } \\
\text { information, education, price signals, } \\
\text { social norms, community interaction } \\
\text { etc. }\end{array}$ & $\begin{array}{l}\text { Practices circulate and change through } \\
\text { changing or mixing elements, and } \\
\text { through innovation in practice }\end{array}$ \\
\hline $\begin{array}{l}\text { Change is orderly, predictable and } \\
\text { controllable }\end{array}$ & $\begin{array}{l}\text { Change is emergent, dynamic and } \\
\text { often uncontrollable }\end{array}$ \\
\hline $\begin{array}{l}\text { Efficiency improvements and demand } \\
\text { reductions are long-lasting }\end{array}$ & $\begin{array}{l}\text { Practices are constantly changing } \\
\text { along trajectories that may negate } \\
\text { efficiency and conservation } \\
\text { improvements }\end{array}$ \\
\hline
\end{tabular}

Schatzki (2002) distinguishes between a practice as being both a co-ordinated entity and a performance which is actualised and sustained through individuals' reproduction of it. The entity consists of a mix of inter-related elements, of which most practice theorists have their own definitions (see Gram-Hanssen 2009 for a summary). For the purposes of this discussion, I identify these elements as being common understandings about what the practice means and how it is valued, rules about what procedures and protocols must be followed and adhered to, practical knowledge about how to carry out and perform a practice, and material infrastructure —or the 'stuff' that makes the practice possible, sensible and desirable (Shove et al. 2007; Strengers 2009). Elements are not deducible or distinguishable — each should be viewed as interconnected and intersecting with each other (Pantzar \& Shove 2010). 
For example, a practice theory perspective might view the increase in residential air-conditioning as the changing practice of household cooling, involving the complex co-evolution of material infrastructures (changing housing formats, central heating and cooling, the affordability and availability of the airconditioner) (Strengers 2010a); common understandings of air-conditioning as a normal and necessary service (Ackermann 2002; Cooper 1998), and changing notions of 'air' 'health' and ‘wellbeing' associated with indoor climate and temperature (Shove 2003); practical knowledge about how to cool the body and home (Strengers \& Maller 2011); and rules about how to use and install the airconditioner (Kempton et al. 1992). This is distinct from accounts of the airconditioner's rapid diffusion in western societies that privilege processes of market economics (affordability and availability), cultural symbolism (the airconditioner's role as a 'status' object), or changing individual choices and lifestyle needs.

Table 1 also highlights the different role afforded to technologies and infrastructures in some social practice theories. In following a significant 'posthumanist' minority from the field of science and technology studies (Schatzki 2001), this paper positions technologies and infrastructures as a key element of practices: they take on the role of 'actants that can suggest and transform practices' (Hawkins \& Race 2011: 115). The inclusion of material infrastructure as an element of practices marks a significant departure from the supply-demand divide permeating the energy sector, in which technologies and human action are clearly separated and subject to different disciplinary approaches and models of change (e.g. engineering versus psychology). In 
contrast, energy technologies and infrastructures 'necessarily participate in social practices just as human beings do’ (Reckwitz 2002a: 208).

Another critical distinction noted in Table 1 is the shift in focus from the consumption of resources, to the practices in which all consumption is implicated (Warde 2005). In other words, people consume resources in order to carry out the day-to-day practices that they make possible (Warde 2005). In this context, peak electricity demand policies and programs are responding to changing social practices, and in particular, to the resource constraints and challenges these pose. This is not, in and of itself, a unique insight. The energy industry often talks about 'end-use services' as being the 'driver' of demand, recognising that it is the activities that use energy which generate demand. However, where a practice theory perspective differs is that these end-use services are not viewed as the outcome of attitudes, behaviours or choices (ABC), but rather as the product of social practices.

In summary, social practice theory provides a distinct account of everyday life and social change which differs markedly from the ABCD model. The focus shifts from individual and autonomous agents, or self-directive and purposive technologies, and onto assemblages of common understandings, material infrastructures, practical knowledge and rules, which are reproduced through daily routines. It follows that the role of the demand manager is also repositioned. They can no longer be seen as purposive agents in the process of change, steering practices on particular courses. Their ability to affect change is 'complicated and qualified’ by the ‘emergent and uncontrollable trajectories’ of practices (Shove \& Walker 2010: 475). Such qualifications necessarily reframe and potentially reject 
the role of traditional change agents in the reproduction and transformation of everyday life — requiring attention to what role they do, or might have, in reorienting and reordering it.

\section{Reframing the peak electricity demand problem}

The role of demand managers depends, in part, on the ways in which the problems they seek to address are defined, and the strategies they employ to address them are established. Table 2 contrasts dominant ABCD questions used to frame the issue of peak electricity demand with those that might emerge from social practice theory. There is a fundamental shift in the units of enquiry and analysis: from resource consumption, technologies and individual behaviours; to social practices, their elements and carriers. Alternative approaches are identified by examining how practices are changing and likely to change into the future, rather than extrapolating current resource consumption growth rates and projecting them forward (see Table 2). 
Table 2: Contrasting social theories applied to the issue of peak electricity demand

\begin{tabular}{|c|c|c|c|c|c|}
\hline \multicolumn{3}{|c|}{ ABCD Theories } & \multicolumn{3}{|c|}{ Social Practice Theories } \\
\hline Questions & $\begin{array}{l}\text { Units of enquiry/ } \\
\text { analysis }\end{array}$ & Approach & Questions & $\begin{array}{l}\text { Units of enquiry/ } \\
\text { analysis }\end{array}$ & Approach \\
\hline $\begin{array}{l}\text { Why is peak electricity demand } \\
\text { rising? }\end{array}$ & Resource demand & $\begin{array}{l}\text { Analyse market trends in } \\
\text { appliance usage and sales }\end{array}$ & $\begin{array}{l}\text { Why is peak electricity } \\
\text { demand rising? }\end{array}$ & Practices & $\begin{array}{l}\text { Identify which practices } \\
\text { are contributing to } \\
\text { changing demand; analyse } \\
\text { their history and current } \\
\text { trajectory }\end{array}$ \\
\hline $\begin{array}{l}\text { What are the projected demand } \\
\text { trends into the future? }\end{array}$ & $\begin{array}{l}\text { Resource } \\
\text { demand, } \\
\text { demographic } \\
\text { segments }\end{array}$ & $\begin{array}{l}\text { Analyse demand trends } \\
\text { based on current } \\
\text { projections (quantitative } \\
\text { extrapolations) }\end{array}$ & $\begin{array}{l}\text { How and why have } \\
\text { relevant practices } \\
\text { changed? How and why } \\
\text { are they changing now? }\end{array}$ & Practices & $\begin{array}{l}\text { Analyse how and why } \\
\text { practices are changing }\end{array}$ \\
\hline $\begin{array}{l}\text { What are the barriers and drivers } \\
\text { of demand? } \\
\text { How can they be } \\
\text { removed/encouraged }\end{array}$ & $\begin{array}{l}\text { Barriers and } \\
\text { drivers }\end{array}$ & $\begin{array}{l}\text { Identify barriers and } \\
\text { drivers. Provide } \\
\text { information, education and } \\
\text { incentives to overcome/ } \\
\text { encourage them }\end{array}$ & $\begin{array}{l}\text { What are the processes } \\
\text { of practice change? How } \\
\text { can they be supported? }\end{array}$ & Practices & $\begin{array}{l}\text { Support and encourage } \\
\text { innovation in practice; } \\
\text { attempt to reorient practice } \\
\text { elements }\end{array}$ \\
\hline $\begin{array}{l}\text { Which behaviours should be } \\
\text { encouraged and what demand } \\
\text { should be shifted? }\end{array}$ & $\begin{array}{l}\text { Load profiles, } \\
\text { Social norms and } \\
\text { values }\end{array}$ & $\begin{array}{l}\text { Identify 'discretionary' and } \\
\text { 'non-discretionary' } \\
\text { demand. Discretionary } \\
\text { demand targeted }\end{array}$ & $\begin{array}{l}\text { How are needs and } \\
\text { wants constructed? How } \\
\text { could they be } \\
\text { constructed differently? }\end{array}$ & $\begin{array}{l}\text { Practices, needs and } \\
\text { expectations }\end{array}$ & $\begin{array}{l}\text { Analyse how needs and } \\
\text { wants are constructed } \\
\text { through practices. Identify } \\
\text { and support processes of } \\
\text { change }\end{array}$ \\
\hline $\begin{array}{l}\text { How can people be educated to } \\
\text { better manage their demand? }\end{array}$ & $\begin{array}{l}\text { Resource } \\
\text { management } \\
\text { knowledge and } \\
\text { information }\end{array}$ & $\begin{array}{l}\text { Promote information and } \\
\text { education that encourages } \\
\text { household resource } \\
\text { management }\end{array}$ & $\begin{array}{l}\text { How can new practical } \\
\text { knowledge, common } \\
\text { understandings and rules } \\
\text { be circulated? }\end{array}$ & $\begin{array}{l}\text { Practices (practical } \\
\text { knowledge, common } \\
\text { understandings and } \\
\text { rules) }\end{array}$ & $\begin{array}{l}\text { Assist in the circulation of } \\
\text { alternative practical } \\
\text { knowledge, common } \\
\text { understandings and rules }\end{array}$ \\
\hline $\begin{array}{l}\text { How can people be encouraged } \\
\text { to make cost-reflective decisions } \\
\text { about their consumption during } \\
\text { peak times? }\end{array}$ & $\begin{array}{l}\text { Individual } \\
\text { behaviours and } \\
\text { drivers; pricing } \\
\text { signals }\end{array}$ & $\begin{array}{l}\text { Develop cost-reflective } \\
\text { pricing programs or } \\
\text { incentive schemes to shift } \\
\text { or shed peak demand. }\end{array}$ & $\begin{array}{l}\text { How do common } \\
\text { understandings and rules } \\
\text { emerge from different } \\
\text { pricing schemes? }\end{array}$ & $\begin{array}{l}\text { Practices (common } \\
\text { understandings and } \\
\text { rules) }\end{array}$ & $\begin{array}{l}\text { Identify pricing schemes } \\
\text { that facilitate less peaky } \\
\text { practices by reorienting the } \\
\text { elements of these practices }\end{array}$ \\
\hline $\begin{array}{l}\text { How can demand be made more } \\
\text { efficient? }\end{array}$ & $\begin{array}{l}\text { Efficient and } \\
\text { load-shifting } \\
\text { technologies }\end{array}$ & $\begin{array}{l}\text { Identify and promote } \\
\text { efficient and 'smart' } \\
\text { technologies }\end{array}$ & $\begin{array}{l}\text { How are technologies } \\
\text { and infrastructures co- } \\
\text { shaping practices? }\end{array}$ & Practices & $\begin{array}{l}\text { Identify and support } \\
\text { technology and } \\
\text { infrastructure that enables } \\
\text { less peaky practices. }\end{array}$ \\
\hline
\end{tabular}


Rather than being viewed as a definitive framework, theory or method, these questions reposition the policy problem of peak electricity demand. Instead of asking how demand can be shaved or shifted, demand can be more usefully thought of as a symptom or by-product of changing social practices. The aim becomes one of understanding the elements and reproduction of problematic peaky practices, and attending to the dynamics of transformation and innovation that are occurring. Section 5 provides some insight into how and where these opportunities might arise, and how this repositions and broadens the role of demand managers.

\section{Repositioning the role of demand managers}

\subsection{Rethinking provider-consumer relationships}

As discussed in Section 2, electricity systems are currently managed within supply-demand siloes. This prioritises a provider-consumer relationship (Guy \& Marvin 2001), whereby the provider's role is to provide and maintain the supply of resources, and the consumer's role (and right) is to consume them. In the context of peak electricity demand, this is a problematic relationship, and one which legitimises 'rights' to peaky practices (such as air-conditioning) or services (unwavering electricity demand) as non-negotiable needs (Shove \& Chappells 2001). In contrast, we can conceptualise the electricity system (supply)—as vast and intractable as it might seem—as an element of electricity-consuming social practices, informing what makes sense for householders to do during (and outside) peak periods.

Small-scale case studies of localised, community managed or distributed supply systems, such as solar panels (ATA 2007) and micro grids (Chappells \& Shove 2004), provide examples of the dynamics involved when the supply-demand divide is collapsed and electricity systems become an active element in the 
practices they enable. Discussing micro grids in the UK, Chappells \& Shove (2004: 139) suggest that:

in these situations the distinction between provider and consumer collapses, opening up new opportunities for the coordination of demand and supply and for the 'real-time' management of resources and resource-consuming activities.

In this example, the electricity system realigns other practice elements and reorients current routines. In practice, this might involve householders' turning off unused or ‘unnecessary’ appliances, rescheduling ‘discretionary’ practices such as laundering to times when there is adequate demand, or seeking alternative ways to undertake practices, such as putting on a jumper or going for a brisk walk in cold weather instead of turning the heater on. Such situations create opportunities for new needs to take hold around the variability of supply, similar to the ways in which consumers react and adapt to fuel restrictions.

Following this line of enquiry, Marvin \& Perry (2005: 86) found that during the UK fuel crisis of 2000, network disruptions shaped 'innovative coping strategies that may have the potential for reshaping the user's relations with the network'. In their study of people's capacity to cope with this short-term crisis, they suggest that users adopt three main strategies: (i) they suspend their existing meetings or don’t attend work; (ii) they adjust the way they get to work by car sharing or altering other domestic routines; and (iii), they adapt their normal routines significantly to cope with the crisis, such as working from home (Marvin \& Perry 2005). 
In these examples, the role of the consumer changes: they are no longer passive recipients of complex networks and systems (electricity or fuel), but co-managers of their own practices, involving dynamics of both supply and demand (Chappells \& Shove 2004; Strengers 2011a; Van Vliet et al. 2005). This is distinct from the expectation for constant and unwavering demand embedded into modern electricity systems, policies and regulations. Trentmann (2009: 80) highlights the problematic nature of this expectation, whereby consumers must be 'protected' from disruption, while they simultaneously 'play an active role in absorbing and coordinating them, in some cases even generating them'.

In Australia, this is most clearly illustrated in the example of residential cooling practices involving air-conditioning, which can lead to blackouts on hot summer days. Utilities are legally obligated to upgrade electricity infrastructure in attempts meet this demand, despite the inefficiencies and costs it creates for networks and consumers (Strengers 2010a). These interactions between supply and demand remain largely unaddressed in the policy and strategy siloes that dominate the energy sector. A practice theory perspective encourages us to collapse the separate roles and responsibilities of 'suppliers' and 'demanders', to critically examine how electricity systems uphold or challenge existing (problematic) needs, and how they can potentially enable innovative co-management opportunities.

Such attempts do not necessarily need to involve new material infrastructures such as micro-grids, or 'crises' such as blackouts and fuel restrictions, but may relate to the rules or common understandings associated with existing supply systems. For example, variable pricing regimes, such as dynamic (or critical) peak 
pricing, or load limiting schemes whereby householders agree to cap their peak demand, can replicate the disruption and variability of a large-scale electricity systems at the household scale. While these demand management strategies are primarily framed within a supply-demand paradigm, whereby suppliers must compensate and entice consumers to shift their demand, they could also be reconceptualised as a form of co-management.

For example, in Australia dynamic peak pricing commonly refers to an electricity pricing scheme that charges 10-40 times the off-peak rate of electricity during peak 'events' that last for approximately four hours and are called up to 12 times a year (generally on very hot or cold days). This pricing strategy is designed to shift or shed demand during short peak periods to avoid power shortages resulting from peak electricity demand. The viability of this approach was evaluated in a small study of Australian households, who were found to re-arrange their daily routines in response to this price signal, self-imposing their own blackouts or power cuts by undertaking alternative practices, shifting peaky practices to other times of the day, switching off power at the meter box or power point, and/or leaving the house (Strengers 2010a).

Similar to the studies discussed above (Chappells \& Shove 2004; Marvin \& Perry 2005), in this 'man-made' disruption 'the temporal fragility of habits and the elasticity of everyday life' (Trentmann 2009: 68) was revealed as householders demonstrated their creativity and practical skills in re-organising and innovating daily routines. Here, the price signal took on the role of revealing the peakiness of the electricity system—resulting in non-discretionary practices, such as airconditioning, being called into question. These findings support Trentmann's call 
for a more critical examination of the role of breakdowns and disruptions in managing everyday life—-through pricing schemes, micro-grid systems or loadlimiting programs (whereby the electricity load delivered to a home is controlled, varied or limited in line with the inherent fluctuations of the system). For demand managers, this might mean facilitating alternative relationship arrangements, or forms of co-management, which activate or accentuate the materiality of electricity systems as an element of social practices.

\subsection{Working beyond the scale of demand}

Another practical strategy for demand managers is to refocus their attention beyond traditional boundaries and understandings of demand. In thinking about how practices are co-constructed, demand managers can identify a wider range of human and non-human stakeholders that are either deliberately or inadvertently involved in shaping and shifting the elements of peaky practices. Rather than seeing such issues beyond the scope of their role, a practice theory perspective necessitates viewing them as being integral to it.

For example, there are opportunities to think beyond the domain of the home in attempts to keep people cool. There may be scope to consider the establishment of 'cooling centres' or to promote and expand existing cool destinations, such as libraries, cinemas, pools, shopping centres and other community facilities, that shift peak cooling practices outside the home (Strengers \& Maller 2011). Similar to Australia’s bush fire policy, one might imagine a ‘stay or go’ plan for households experiencing extreme heat, and the promotion of 'heat plans' and 'heat hotlines' for those at risk. This does not seem unreasonable when we consider that heat stress causes more deaths than floods, cyclones and bushfires 
(Maller \& Strengers 2011). Such activities potentially reorient the elements of peak cooling practices; for example, the material infrastructure of the home may no longer be considered essential to staying cool. This creates opportunities for other practice elements to adjust and realign in ways that potentially meet the objectives of demand managers.

Thinking within the domain of the home, changing housing designs and infrastructures have played a critical role in normalising air-conditioning appliances to produce new practices of household cooling (Ackermann 2002; Shove 2003). In Australia, these changes have included the rise of open-plan living and central heating and cooling, combined with substantial increases in floor space and the decline in some thermal features such as eves (DEWHA 2008; Strengers 2010a; Wilkenfeld 2004). In contrast, a house designed to prioritise passive thermal comfort, using appropriately placed windows, blinds and shading, potentially changes what makes sense for householders to do to achieve 'coolth' (Prins 1992). Studies of adaptive thermal comfort support this proposition, finding that building occupants exposed to a range of 'passive' technologies and infrastructures tolerate and enjoy a wider band of temperatures than those living in climate-controlled situations (Brager et al. 2004; Nicol \& Roaf 2007). In contrast, policies and regulations that encourage, or do little to discourage, the trend towards central heating and cooling, serve to legitimise and normalise a particular form of energy-intensive comfort (Chappells \& Shove 2005). De Dear and Brager (2002: 550) elaborate:

People living year-round in air-conditioned spaces are quite likely to develop high expectations for homogeneity and cool 
temperatures, and may become quite critical if thermal conditions in their buildings deviate from the centre of the comfort zone they have come to expect. In contrast, people who live or work in naturally ventilated buildings where they are able to open windows, become used to thermal diversity that reflects local patterns of daily and seasonal climate variability.

These authors point to the ways in which housing infrastructures prioritise needs and expectations for particular types of cooling. In this way, we can see how houses, and the technologies and infrastructures which constitute them, can also be viewed as elements of practices which deserve further attention from demand managers.

However, while housing is often identified as a major 'contributor' or 'factor' to changing expectations of cooling, there is no way of addressing it within the ABCD model, apart from encouraging householders to buy more thermally efficient houses, or make relevant retrofit choices when they renovate their home. More worryingly, because peak electricity demand is primarily framed as an ‘energy’ issue rather than a housing one, such concerns are not addressed in housing policy — where relevant policies and regulations are formulated (Strengers \& Maller 2011). Equally problematically, professions that might influence the practices of household cooling, such as planners, designers, builders and developers, see these concerns as being largely beyond their role.

Without addressing these issues, the role of demand managers may be limited to one of advocacy or negotiation with the housing sector. Some demand managers 
have attempted this task with limited success However, many more have not tried because they view this activity as being beyond the scope of their role (Strengers 2010b). A crucial aspect of the problem is that those who are not tasked with the role of changing demand (such as the housing industry) have a substantial influence on its continuing transformation. Such issues serve to illustrate how the traditional siloes of energy policy and management inadvertently promoted by the supply-demand paradigm leave integral elements of practices overlooked or dismissed.

\subsection{Promoting new wants and needs}

A far more blatant approach for demand managers, or any self-identified change agent, is to actively debate and challenge taken for granted lifestyle 'needs'. Unlike advertisers and marketers, who study current practices in order to change or reinforce them, demand managers spend a lot of time and money asking consumers what their needs are, but make very few attempts to establish new ones. Indeed, in many cases they go out of their way to uphold assumed needs by, for example, encouraging pre-cooling prior to a dynamic peak pricing event, which reinforces the assumed need for air-conditioning during these times (see, for example, CountryEnergy 2004).

Where attempts to instigate change are made, resource-centric information and awareness campaigns focus on 'saving' resources and money, yet fail to address expectations and needs—indeed in most cases they explicitly avoid them. For example, Sustainability Victoria’s (SV 2009) public media campaign encouraging householders to switch to cold water in the laundry in order to save money and energy overlooks the reasons why people use hot water in the first place, namely to produce clean and hygienic clothing. Within this context, the energy sector's 
focus on appealing to householders’ green motives, encouraging rational cost reflection, and providing consumption feedback, is often drowned out by the promotion of new expectations and aspirations associated with practices (such as the need to maintain higher levels of hygiene and cleanliness), and/or the commitment or nostalgic attachment to continuing domestic traditions (such as how someone was taught to do their laundry).

The silence from demand managers on subjects considered a matter of 'personal choice’ can be partly attributed to understandings of their roles.

For example, it is not normally considered the responsibility of demand managers to comment on the whiteness and brightness of laundry. Furthermore, such matters are considered 'private' and 'personal', rather than the domain or responsibility of utilities, NGOs and governments. In contrast, these issues are core business for marketing and advertising agencies (such as Datamonitor (2008a, 2008b)), who keep track of current trends and changing practices, providing advice to companies on where gaps exist for new or existing products. Marketing agencies attempt, with varying degrees of success, to insert new common understandings, material infrastructures, and rules into practices, and provide practical knowledge about how to do them better (usually in ways that require specific products). In short, they promote practices (Shove \& Pantzar 2005), borrowing elements from others (such as common understandings of hygiene and cleanliness) to achieve their aims, in some cases counteracting the objectives of demand managers.

There is a strong need to critically reflect on the type of promotion demand managers currently do, and to shift from promoting energy and financial savings, 
to promoting (and debating) practices. This means that, rather than trying to establish and embed new environmental, resource-oriented and economic understandings into every practice—a strategy which is likely to result in 'preaching to the converted' — demand managers should consider playing a more active role in shaping or counteracting the elements already associated with practices, or facilitate opportunities for new ones to form. Drawing again on the laundry example, this might involve attempting to counteract the assumption that cold water doesn't clean clothes as effectively as warm or hot water, an approach cold water detergent promoters are already taking (see for example Colgate 2010). This is a matter of thinking about and attempting to shift the understandings embedded into a practice, rather than attempting to instil new environmental morals and economic responsibility into individuals.

In many ways, demand managers are already well aware of these strategies, although they are often applied to achieve the opposite objective; namely to increase resource consumption. This is due to the simple reason that, notwithstanding considerable efforts to encourage energy conservation and efficiency, most energy utilities still make money by selling power (Strengers 2010b). For example, the Australian retailer Origin Energy has a strong focus on environmental sustainability in all of its marketing materials, but is actively involved in promoting a range of energy appliances through its store, including air-conditioners (Origin 2012). In promoting efficient air-conditioners to households that may or may not have one, utilities are effectively promoting airconditioning and the cooling practices it enables (Shove 2004). 
The issue is slightly more complicated for electricity distributors, who have an economic incentive to shift peaky practices to other times of the day, but no real incentive to reduce them . An efficient distribution and transmission network is one where 'hot spots' of demand are moved into 'cold spots', creating an even, steady load of electricity at all times (Guy \& Marvin 1996). Using the example of household cooling, this would mean that distributors have the most to gain from encouraging pre- and post-cooling outside peak events, or indeed encouraging 24hour climate controlled environments where there is constant and consistent load, thereby increasing, reinforcing and potentially stabilising the expectation for climate-controlled residential environments. Such issues suggest the need to pay attention not only to the peaky and resource-intensive practices of householders, but also to the practices of demand managers, and their agency to affect change.

\section{Assigning agency and identifying agents}

This paper began by identifying demand managers as change agents, implying that they have the agency to affect and direct change. Before concluding, it is worth clarifying how understandings of agency and agents necessarily differ between $\mathrm{ABCD}$ and social practice theories. In the ABCD model, agency is attributed to individuals, as self-interested and rational agents who have the power and choice to change their own actions - and to demand managers, who have the power to change people. In practice theory, this agency does not disintegrate, but rather is redirected and circulated through the reproduction of practices, where:

....agents are body-minds who 'carry' and 'carry out' social practices. Thus, the social world is first and foremost populated by diverse social practices which are carried out by agents (Reckwitz 2002b: 256). 
In this sense, two sets of practices become critical to any discussion concerning agency and change: the practices of demand management, which are carried out by demand managers; and the peaky practices that demand managers seek to change, which are primarily carried out by householders. Both sets of practices raise critical insights for assigning and understanding agency.

The first encourages attention to the practices involved in shifting and shedding demand. The delivery of strategies such as variable pricing, consumption feedback and direct load control can be conceptualised as historical situated practices, subject to their own 'pockets of stability and pathways of innovation' (Shove 2010: 1278). Such strategies are invariably bound and contained by common understandings, practical knowledge, rules and material infrastructures defining what it means to manage demand, and what responsibilities are assigned to the professions tasked with that role. While this paper has not focused on these demand management practices, and the routes of change that might be open to reconfiguring them, this is a worthy topic for future investigation.

The second set of practices concerns those that demand managers seek to change; the everyday practices that are carried out by householders. Rather than ascribing demand managers with the agency to change these practices, we could reconceptualise these professions as potential manipulators of household practices - that is, people who (to varying degrees of success) are attempting to shift practice entities and contribute to new forms of circulation and reproduction. However, the successfulness of their attempts depends on the ways in which these changes are resisted or incorporated into the practice performances of 
householders. This redirects demand managers to attend to the more complicated and subtle role they (and others outside their professions) play in reorienting social practices and their elements, not necessarily deliberately or predictably.

This redirection of agency and agents is not merely a matter of semantics—it has quite profound impacts on what 'making change' means and how it happens. If an ABCD understanding of agency remains, there is a legitimate concern that the change agent professions will attempt to 'target' and 'drive' specific practices (as they currently target individuals) deemed 'good' or 'bad', 'discretionary' or 'nondiscretionary’. Furthermore, they will overlook the important role of material infrastructures, which can also take the form of a change agent, reorienting other elements of practices as is the case with electricity systems, air-conditioners and housing infrastructures.

We might then conclude that the term 'change agent' is inherently unhelpful in moving beyond theories of demand: firstly, because social practice theory suggests that the change agent professions do not have the agency to affect change, at least not in the purposive sense commonly assumed; and secondly, because labelling one group of professions ‘change agents’ reinforces a siloed understanding of social change, where some professions can and should make change happen, whereas other potentially influential ones (like engineers) can’t and shouldn't.

Alternatively, social practice theory points towards the identification and establishment of a new breed of change agents that extend beyond the demand management professions, and are both deliberately and inadvertently 
reconfiguring the elements of problematic practices. Using the example of the changing practices of household cooling, these agents might include airconditioning technologies and their designers, manufacturers and marketers; housing infrastructures and their developers, builders, planners and policymakers; and the engineers, regulators and policy-makers involved in planning, designing, building and co-ordinating the large energy systems on which peaky (and non-peaky) practices now depend.

Of course, we must not forget the most critical change agents of all; the performers of household practices, those everyday innovators who, in the context of extreme heat, blackouts and changing cooling technologies, are variously involved in inventing and adapting ways to keep cool (Strengers \& Maller 2011). In contrast to demand management's current preoccupation with security supply and maintaining (or enhancing) current 'needs', these agents of everyday life demonstrate considerable adaptiveness and inventiveness in modifying, scheduling and transforming current routines when the elements of practices are reconfigured.

\section{Conclusion}

In the energy sector, where an ABCD model pervades attempts to shift and shed peak demand, social practice theory provides an alternative framing which significantly redefines the problem and potential responses to this internationally significant issue. From this perspective, the problem of peak demand can be usefully viewed as a symptom of changing expectations and conventions associated with everyday household practices, such as cooling, heating and entertaining. Wants, needs, values and expectations, which are commonly 
understood as originating from humans, emerge from and within practices. This perspective reorients the purpose and function of change agent professions such as demand managers.

This paper has argued that going beyond the human mind allows for a more complex understanding of the ways in which changing elements of social practices construct and generate particular expectations for energy services and the practices they enable. This perspective potentially challenges the electricity industry’s current preoccupation with securing the electricity grid, preserving current services, and protecting consumers from their fluctuating demand—all of which serve to reinforce and potentially accelerate the very expectations that cause peak demand in the first place. Social practice theory can refocus attention on the changing elements of problematic peaky practices undertaken within the household, and on the human and non-human 'stakeholders’ deliberately and inadvertently reorienting their trajectories.

The shift from people to practices challenges not only what the role of a change agent might be, but who a change agent is. An engineer designing a new load management technology or upgrading the distribution network may be as important, if not more so, than the traditional change agent professions of behaviour change and demand management. Similarly, policy makers tasked with the role of achieving social and behavioural change are as relevant as those making policy concerning electricity or housing infrastructure. Social change can no longer be thought of as a confined process that takes place by manipulating and coercing human minds, but rather as a suite of transforming and intersecting social practices constituted by understandings, practical skills, rules and things. In 
this sense, directly or indirectly positioning certain professions as change agents may prove unhelpful, given that such labels mask and potentially dismiss other processes and avenues of social transformation. Instead, an alternative breed of change agents needs to be identified and established that are involved, both deliberately and indirectly, in reconfiguring the elements of peaky and resourceintensive practices.

For those professions assigned the task of managing demand, this perspective may appear challenging —indeed it cuts to the core of what it means to 'be' a demand manager and 'do' demand management. Further work is required to understand how the practices of demand management are configured, what trajectories they are on, and what opportunities there are to facilitate change within these professions. In the meantime, traditional change agents can use this perspective to reframe problems in a new light, innovate beyond the boundaries of their role, and practice new forms of demand management that may send practices on less peaky trajectories. In accepting this challenge, they may bear witness to new and innovative forms of social change that are so urgently required. 


\section{References}

Accenture 2011, Revealing the values of the new energy consumer: Accenture end-consumer observatory on electricity management 2011, Accenture, USA.

Ackermann, M 2002, Cool comfort: America's romance with air-conditioning, Smithsonian Institution Press, Washington, USA.

AEMC 2011, Issues Paper: Power of choice - giving consumers options in the way they use electricity, Australian Energy Market Corporation (AEMC), Sydney, Australia.

ATA 2007, The Solar Experience: PV System Owners' Survey, Alternative Technology Association, Melbourne, Australia.

Brager, G, S, Paliaga, G \& De Dear, RJ 2004, 'Operable windows, personal control, and occupant comfort', ASHRAE Transactions, vol. 4695, no. RP-1161: 17-35.

CEA 2011, Unlocking the potential of the smart grid - a regulatory framework for the consumer domain of smart grid, Consumer Electronics Association (CEA), Arlington, USA.

Chappells, H \& Shove, E 2004, 'Infrastructures, crises and the orchestration of demand', in D Southerton, B Van Vliet \& H Chappells (eds), Sustainable Consumption: the Implications of Changing Infrastructures of Provision, Edward Elgar, Cheltenham, UK, 130-43.

Chappells, H \& Shove, E 2005, 'Debating the future of comfort: environmental sustainability, energy consumption and the indoor environment', Building Research and Information, vol. 33, no. 1: 32-40.

Colgate 2010, Cold Power Advanced, Colgate-Palmolive Company, viewed 5 July 2010, $<$ http://www.colgate.com.au/app/PDP/2xUltraConcentrate/AU/cold-power-2xultradetergent-liquid-and-powder.cvsp $>$.

Cooper, G 1998, Air-conditioning America: Engineers and the Controlled Environment, 19001960, The John Hopkins University Press, Baltimore, USA.

CountryEnergy 2004, Here's everything you need to know to make an informed decision. The CountryEnergy Home Energy Efficiency Trial, CountryEnergy, Sydney.

Darby, S 2010, 'Smart metering: what potential for householder engagement?', Building Research \& Information, vol. 38, no. 5: 442 - 57.

Datamonitor 2008a, The Future of Home Hygiene and Clothing Care Occasions, Datamonitor, viewed 3 March 2009, <http://www.datamonitor.com/consumer>.

Datamonitor 2008b, Sterilized Society: Consumer Attitudes Towards Hygiene and Cleanliness, Datamonitor, viewed 3 March 2009, <http://www.datamonitor.com/consumer>.

de Dear, RJ \& Brager, G, S 2002, 'Thermal comfort in naturally ventilated buildings: revisions to ASHRAE Standard 55', Energy and Buildings, vol. 34, 549-61.

DEWHA 2008, Energy Use in the Australian Residential Sector 1986-2020, Australian Government: Department of the Environment, Water, Heritage and the Arts (DEWHA), Canberra, Australia.

ETSA 2007, Demand Management Program: Interim Report No. 1, ETSA Utilities, Adelaide, SA.

Gram-Hanssen, K 2009, 'Standby consumption in households analyzed with a practice theory approach', Research and Analysis, vol. 14, no. 1: 150-65.

Guy, S \& Marvin, S 1996, 'Transforming urban infrastructure provision - the emerging logic of demand side management', Policy Studies, vol. 17, no. 2: 137-47.

Guy, S \& Marvin, S 2001, 'Urban environmental flows: towards a new way of seeing', in S Guy, S Marvin \& T Moss (eds), Urban Infrastructures in Transition: Networks, Buildings, Plans, Earthscan Publications Ltd, London, UK, 22-40.

Guy, S \& Shove, E 2000, A Sociology of Energy, Buildings and the Environment, Routledge, London [UK].

Harrington, L, Jones, K \& Harrison, B 2006, 'Trends in television energy use: where it is and where its going', paper presented to 2006 ACEEE Summer study on energy efficiency in buildings, Asilomar Conference Centre, Pacific Grove, California, 13-18 August.

Hawkins, G \& Race, K 2011, 'Bottle water practices: reconfiguring drinking in Bangkok households', in R Lane \& A Gorman-Murray (eds), Material geographies of household sustainability, Ashgate, Farnham, UK, 113-24.

Herter, K 2007, 'Residential implementation of critical-peak pricing of electricity', Energy Policy, vol. 35, 2121-30.

Hobson, K 2006, 'Bins, bulbs, and shower timers: on the "techno-ethics' of sustainable living', Ethics, Place and Environment, vol. 9, no. 3: 317-36.

Kempton, W, Feuermann, D \& McGarity, AE 1992, "'I always turn it on super": user decisions about when and how to operate room air conditioners', Energy and Buildings, vol. 18, 177-91. 
Kempton, W \& Montgomery, L 1982, 'Folk quantification of energy', Energy, vol. 7, no. 10: 81727.

Lutzenhiser, L 1993, 'Social and behavioral aspects of energy use', Annual Review of Energy and the Environment, vol. 18, 247-89.

Maller, CJ \& Strengers, Y 2011, 'Housing, heat stress and health in a changing climate: promoting the adaptive capacity of vulnerable households, a suggested way forward', Health Promotion International, vol. 26, no. 1: 100-8.

Marvin, S \& Perry, B 2005, 'When networks are destabilized: user innovation and the UK fuel crises', in O Coutard, RE Hanley \& R Zimmerman (eds), Sustaining urban networks: The social diffusion of large technical systems, Routledge, London, UK, 86-100.

NERA 2008, Cost Benefit Analysis of Smart Metering and Direct Load Control. Work Stream 4: Consumer Impacts. Phase 2 Consultation Report, NERA Economic Consulting, prepared for the Ministerial Council on Energy Smart Meter Working Group, Sydney, Australia.

Nicol, F \& Roaf, S 2007, 'Progress on passive cooling: adaptive thermal comfort and passive architecture', in M Santamouris (ed.), Advances in Passive Cooling, Earthscan, London, UK, 1-29.

Origin 2012, Origin, viewed 18 January 2012, <http://www.originenergy.com.au/>.

Pantzar, M \& Shove, E 2010, 'Understanding innovation in practice: a discussion of the production and reproduction of Nordic Walking', Technology Analysis \& Strategic Management, vol. 22, no. 4: 447-61.

Pears, A 2004, 'Megawatts or negawatts - distributed and demand-side alternatives to new generation requirements', paper presented to Australian Institute of Energy Symposium Energy in NSW 2004: A Strategic Review, Australian Technology Park, Redfern, Australia, 20 May.

Prins, G 1992, 'On condis and coolth', Energy and Buildings, vol. 18, 251-8.

Reckwitz, A 2002a, 'The status of the 'material' in theories of culture. From 'social structure' to 'artefacts", Journal for the Theory of Social Behaviour, vol. 32, no. 2: 195-217.

Reckwitz, A 2002b, 'Toward a theory of social practices: a development in culturalist theorizing', Journal of Social Theory, vol. 5, no. 2: 243-63.

Reidy, C 2006, Interval Meter Technology Trials and Pricing Experiments: Issues for Small Consumers, Institute of Sustainable Futures, prepared for Consumer Utilities Advocacy Centre, Sydney, Australia.

Schatzki, TR 2001, 'Practice theory', in TR Schatzki, K Knorr Cetina \& E Von Savigny (eds), The Practice Turn in Contemporary Theory, Routledge, New York, USA.

Schatzki, TR 2002, The Site of the Social: a Philosophical Account of the Constitution of Social Life and Change, The Pennsylvania State University Press, Pennsylvania, USA.

Schwartz Cowan, R 1989, More Work for Mother: the Ironies of Household Technology from the Open Hearth to the Microwave, Free Association Books, London, UK.

SGA 2011, Maximising consumer benefits, Smart Grid Australia (SGA), Melbourne, Australia.

Shove 2010, 'Beyond the ABC: climate change policy and theories of social change', Environment and Planning A, vol. 42, 1273-85.

Shove 2011, 'Commentary: On the different between chalk and cheese - a response to Whitmarsh et al's comments on "Beyond the ABC: climate change policy and theories of social change"', Environment and Planning A, vol. 43, 262-4.

Shove, E 2003, Comfort, Cleanliness and Convenience: the Social Organisation of Normality, Berg Publishers, Oxford, UK.

Shove, E 2004, 'Efficiency and consumption: technology and practice', Energy \& Environment, vol. 15, no. 6: 1053-65.

Shove, E \& Chappells, H 2001, 'Ordinary consumption and extraordinary relationships: utilities and their users', in J Gronow \& A Warde (eds), Ordinary Consumption, Routledge, London, UK, 45-58.

Shove, E \& Pantzar, M 2005, 'Consumers, producers and practices: understanding the invention and reinvention of Nordic walking', Journal of Consumer Culture, vol. 5, no. 1: 43-64.

Shove, E \& Pantzar, M 2007, 'Recruitment and reproduction: the carriers of digital photography and floorball', Human Affairs, vol. 17, 154-67.

Shove, E \& Walker, G 2010, 'Governing transitions in the sustainability of everyday life', Research Policy, vol. 39, 471-6.

Shove, E, Watson, M, Hand, M \& Ingram, J 2007, The Design of Everyday Life, Berg, Oxford [UK].

Sofoulis, Z 2011, 'Skirting complexity: the retarding quest for the average water user', Continuum: Journal of Media \& Cultural Studies, vol. 25, no. 6: 795-810.

Southerton, D, Warde, A \& Hand, M 2004, 'The limited autonomy of the consumer: implications for sustainable consumption', in D Southerton, B Van Vliet \& H Chappells (eds), 
Sustainable Consumption: the Implications of Changing Infrastructures of Provision, Edward Elgar, Cheltenham, UK, 32-48.

Strengers, Y 2009, 'Bridging the divide between resource management and everyday life: smart metering, comfort and cleanliness', PhD thesis, RMIT University.

Strengers, Y 2010a, 'Air-conditioning Australian households: a trial of Dynamic Peak Pricing', Energy Policy, vol. 38, no. 11: 7312-22.

Strengers, Y 2010b, 'Comfort expectations: the impact of demand-management strategies in Australia', in E Shove, H Chappells \& L Lutzenhiser (eds), Comfort in a lower carbon society, Routledge, New York, 77-88.

Strengers, Y 2011a, 'Beyond demand management: co-managing energy and water consumption in Australian households', Policy Studies, vol. 32, no. 1: 35-58.

Strengers, Y 2011b, 'Designing eco-feedback systems for everyday life', paper presented to Proceedings of the 2011 annual conference on Human factors in computing systems, Vancouver, Canada.

Strengers, Y \& Maller, C 2011, 'Integrating health, housing and energy policies: the social practices of cooling', Building Research \& Information, vol. 39, no. 2: 154-68.

SV 2009, You have the power. Save energy., Sustainability Victoria, viewed 12 June 2009, $<\underline{\text { http://www.saveenergy.vic.gov.au/>. }}$

Trentmann, F 2009, 'Disruption is normal: blackouts, breakdowns and the elasticity of everyday life', in E Shove, F Trentmann \& RR Wilk (eds), Time, Consumption and Everyday Life: Practice, Materiality and Culture, Berg, Oxford, UK, 67-84.

Van Vliet, B, Chappells, H \& Shove, E 2005, Infrastructures of Consumption: Environmental Innovation in the Utilities Industries, Earthscan, London, UK.

Warde, A 2005, 'Consumption and theories of practice', Journal of Consumer Culture, vol. 5, no. 2: 131-53.

Wilhite, H, Shove, E, Lutzenhiser, L \& Kempton, W 2000, "The legacy of twenty years of energy demand management: we know more about individual behaviour but next to nothing about demand', in E Jochem, J Sathaya \& D Bouille (eds), Society, Behaviour and Climate Change Mitigation, Kluwer Academic Publishers, The Netherlands, 109-26.

Wilk, RR \& Wilhite, H 1985, 'Why don't people weatherize their homes? An ethnographic solution', Energy, vol. 10, no. 5: 621-9.

Wilkenfeld, G 2004, A National Demand Management Strategy for Small Airconditioners: the Role of the National Appliance and Equipment Energy Efficiency Program (NAEEEP), George Wilkenfeld and Associates for the National Appliance and Equipment Energy Efficiency Committee (NAEEEC) and the Australian Greenhouse Office, Sydney, Australia.

Zpryme 2011, The New Energy Consumer, Zpryme Smart Grid Insights, Austin, USA. 